\title{
A Critical View of the Access to Justice in Brazil
}

\author{
Felipe Probst Werner \\ Law School, Pontifícia Universidade de São Paulo, São Paulo, Brazil
}

\section{Email address:}

lipewerner@hotmail.com

\section{To cite this article:}

Felipe Probst Werner. A Critical View of the Access to Justice in Brazil. International Journal of Law and Society. Special Issue: Access to Justice, Law and Development. Vol. 3, No. 1, 2020, pp. 1-4. doi: 10.11648/j.ijls.20200301.11

Received: February 9, 2020; Accepted: February 20, 2020; Published: March 18, 2020

\begin{abstract}
This article makes critical analyze the access to justice. Beside the concept of this great juridical issue, the main approach is the model and consequences of the free legal aid adopted by Brazilian law system. The study points the problems faced by the country caused by a wrong and incomplete way to provide access to justice. Thru the article, is shown incredible numbers provided by the "Conselho Nacional de Justiça about new lawsuits and the stock of them in Brazilian legal system. In addition, the numbers presented are analyzed and confronted with the free legal aid system which foster the litigation. The article points the problem, its consequences and considerations that could solve the problematic experienced by the Brazilian society. From there, some suggestions are made using concepts and responses obtained with an economic analysis of law as creating more requirements to the concession of the free legal aid. The methodology used is deductive and it is used bibliographical research and case law for the achievement of the study. The result ascertained is that the Brazilian free legal aid model needs urgently a change and because of this, the article finishes proposing new solutions that can solve the presented problem.
\end{abstract}

Keywords: Access to Justice, Free Legal Aid, Economic Analysis of Law

\section{Introduction}

The access to justice is known as a valuable way to distribute equality between the population and users of the legal system.

As a powerful way to guarantee the effectiveness of the complex of laws, the access to justice needs to be in the central of the debates in these modern times because even with the most perfect laws and courts, a legal system could not provide real justice if has absence or lethargic paths to claim and prompt deliver rights.

Thus, besides showing the importance of the access to justice, this article aims to point some critics about one aspect of this great theme that is the free legal aid model adopted by Brazilian law.

To do that, it will be demonstrated what is and should be the access to justice and the impact and distortion that the free legal aid causes on the whole Brazilian legal system.

For the analysis and critics proposed will be used the orthodox doctrine and its concepts but also a law and economics approach.

\section{The Access to Justice}

There is a consensus that the one of the first records known of the access to justice dates from the $18^{\text {th }}$ century and was found on the Hammurabi Code as it allowed that every oppressed man could report to the king their claim, had the right to be listened and be "illuminated" by the solution of his case. $[1,2]$

Developed along the years, the access to justice nowadays is consider an integral category of the Human Rights, as it is possible to note, for example, on the article 8 of the Pact of San José da Costa Rica and on the article 6, 1, first part, of the European Convention of the Human Rights.

In this sense, wise the conclusion of Mauro Cappelletti and Bryant Garth that the access to justice can be seen as a fundamental requirement, the most basic of the human rights, of an equal and modern legal system that aims to ensure the rights of all the population. [3]

There so, it could not be otherwise that the Brazil's 1988 Federal Constitution disposes on its article 5, XXXV that the law cannot exclude of judicial appreciation injury or right threat. 
The promitent Brazilian jurist Luis Guilherme Marinoni features the access of justice as an access to a fair and impartial judicial process that not only enable a proper and effective participation of the parties on the lawsuits, but also allow the effectiveness protection of rights considering the several social positions and specific situations of the material rights. $[4,5]$

According to what is exposed above, the access to justice is composed by a huge array of items that are required to have a complete defense of rights, not just to the lawsuit by itself, but to the information, good guidance and alternative means of conflict composition.

It is very important, however, to add and highlight that the access to justice also means a reasonable duration of the lawsuit. After all, how can the rights be effectively protected if the juridical intervention comes too late to repair a damage? On this point deserves to be remembered a celebrated phrase of Rui Barbosa: "overdue justice is not justice, but a qualified and manifest injustice".

As a matter of fact, if the concession of the justice is belated, there will be no space for effectiveness because the practical effect of the judicial decision probably will no longer satisfy the winner of the lawsuit. [6]

In Brazil, it is possible to mention oodles causes unreasonable duration of lawsuits, as the number of them and its appeals, lack of personal, geographic size, population distribution, legal uncertainty, confusing laws, among others. Some say that even the quantity of law schools and lawyers contributes to spread the problem.

Nevertheless, the focus of this study is the exponential and artificial increase of lawsuits cause by the free legal aid Brazilian system below exposed and its alarming contribution to expand the number of unnecessary and groundless lawsuits.

\subsection{The Problem}

There are no doubts that the main problem of the Brazilian judicial system is the time between the begin and the end of a lawsuit. Even with a decrease in relation to 2018, the numbers provided in 2019 by the "Conselho Nacional de Justiça - CNJ" are shocking.

The average of a lawsuit duration just on the "knowledge" phase is three years and three months-long, if it goes to the "Tribunal de Justiça" (second instance court) we have to add more one year and one month-long, and, when all is all set and the right is recognized by the courts, the jurisdictional have to wait more eight years and a half to have restore effectively his right. [7]

If not enough, the registered number of new lawsuits in 2018, just at the Federated States, was over nineteen million and a half. Although the number of sentences extinguishing them was almost twenty three million, only these courts have more than sixty two million of lawsuits pending judgment.

As earlier exposed, there are several causes to this astronomical numbers, but it is possible to sustain that the free legal aid, as settled on the procedural law, have a great contribution on the chaotic numbers of lawsuits.

To justify what is just said, at the same report made by the $\mathrm{CNJ}$ it is noticed that just supported by the free legal aid were $34 \%$ of the lawsuits in 2018. In 2015, when this kind of reports started, the free legal aid represented $27 \%$ of the total. This means that the situation Is getting worse. [7]

What most alarms, however, is when a litigator is bestowed with the gratuitousness of justice, an empirical study shows that the success of the lawsuit is drastically different from those that doesn't use this kind of benefit. [8]

The study appreciated 1.223 lawsuit proposed and on 767 of them the free legal aid was granted. At the end of them, the surprise was that the lawsuits that did not hava the benefit granted (or required) ware $116 \%$ more successful then those with the free legal aid.

If we use this proportion with the lawsuits filed in 2018 just at the Federated States Courts, it is possible to expect that half of those (approx. 3.3 million) granted with the benefit will be unsuccessful without any consequences.

The huge difference between the outcome of what can be called the "stardard" lawsuits and those granted with the benefit of free legal aid doesn't have another explanation than the ease and absence of risk of filling a lawsuit on the second one.

To make matters worse, according to Luiz Fux and Bruno Bodart, the Brazilian jurisprudence is very generous with the criteria for the grant of the gratuity of justice. [9]

In this way, it is possible to note that a good part of the stock of lawsuits is only there in reason of the model adopted by Brazilian laws and its jurisprudence, which leads to the conclusion that substantial changes are necessary and inevitable

\subsection{The Consequences}

It was pictured above the dramatic problem experienced by the Brazilian legal system. Change this scenario isn't simple neither easy, but once the diagnoses of the disorder is done, it's important to consider at least two aspects to review the entire existing model of free legal aid.

The first of them is the ripple effect on damages and demands. When someone faces a legal system that do not response appropriately becomes common to take this situation into account to make decisions. [10]

Therefore, if the person who is a potential damage causer knows that the response and penalty of the legal system will take a very long time, is more likely that in the sum of factors he will proceed his way to commit the damage, after all, in the meantime between the act of causing damage and the accountability to the judiciary a lot of profit can be made without spending resources preventing damages.

In other words, when a country has a lethargic legal system it seems to be worthy to be a serial damage causer litigator, which, evidently, increases the number of lawsuits.

Concurrently to that, the second aspect the has to be considered is the social cost of a lawsuit.

It is known that the social benefit of a legal system is the social control of the human behavior, as just exposed, the 
idea is to avoid damages and enforce careful conduct. It means that when a legal system works efficiently, the potential damage causer strives to reduce the risk of damage.

Occurs that in the other hand the legal system has its costs, as lawyers, time, private resources, and most important, public resources that could be used on education, public health and public security. [11]

In this way, with a social cost perspective, the legal system will only be worth if the damages avoided or mitigated caused by the change of individuals behavior outweigh the resources consumed.

Joining one aspect with another, the result that is obtained from the Brazilian legal system is not good. As the response comes usually late, less are care acts and more are the damages. With increasing damages even slower the courts become.

The situation starts do scare when added the legal aid ingredient, this free and no risk ride contributes with more than a third of the existing lawsuits, plaguing the judicial system of artificial litigation.

Something have to be done.

\section{Final Considerations}

This paperwork, focused on the free legal aid, tried to demonstrate the Brazilian legal system picture.

There is no doubt that something is wrong, need immediately correction, and, so far, the orthodox way to produce and interpretation of the law was not able to solve the problem. The remedies used until this moment nor have been able to get away with the problem, but instead proved to be an extra dose of poison to the legal system.

For these reasons, an economic approach could be very helpful because the consequences of this aspect of access to justice is felt by society. The economic analysis of law is a way of observing the law that takes into account the scarcity of resources, the rationality of human being and the trend of avoid risks. [12-14]

According to Richard Posner, the task of economic analysis is to explore the implications of assuming that man is a rational maximizing of his existence and satisfactions, that is, of his personal interests. That's why this approach it's so valuable to solve the problem brought in this article. [15]

It is known that the balance between access to justice and an eventual withdraw of the free legal aid is very hard to achieve, however, the existing formula is currently not working as was expected.

The proposal, therefore, is difficult a little bit more the concession of the gratuity of justice and attribute consequences to lawsuits granted with the free legal aid that in the end are recognized as unnecessary or groundless.

To the concession, for example, it is possible to require that the plaintiff submit his income tax return, or the layoff to it presented to the "Receita Federal do Brasil", to be bestowed with the free legal aid. This requirement is justified because fill a lawsuit alone demands organization and a minimum of bureaucracy, thus, will not be very hard for this same person to maintain regular his situation to the public departments. Note that from the respondent this procedure shall not be required, either because he didn't have to take the trouble to file the lawsuit, or to facilitate his right to ample defense.

At the same time, even if the plaintiff meets the requirements for the concession of the benefit, the result of the lawsuit should bring different consequences to him. If the lawsuit is dismissed by neglect or total absence of grounds the plaintiff has to be penalized.

The penalty could be a fine, the repeal of the gratuity, a seal of new requirement of the gratuity for a year, etc., but has to exist and be implemented.

With these two suggestions ser out above, respected diverging opinions, it is possible to expect a minimization of unreasonable and artificial planted lawsuits, and, with that, a legal system closer to justice.

\section{References}

[1] PALMA, Rodrigo Freitas. História do direito. 5. ed. São Paulo: Saraiva, 2015.

[2] SCHIOPPA, Antonio Padoa. História do direito na Europa: da Idade Média à Idade Contemporânea. São Paulo: Martins Fontes, 2014.

[3] CAPPELLETTI, Mauro e GARTH, Bryant. Acesso à justiça. Trad. Ellen Gracie Northfllet. Porto Alegre: Sergio Antonio Fabris Editor, 2002.

[4] MARINONI, Luiz Guilheme. Novas linhas do processo civil. 3 ed. São Paulo: Malheiros, 1999.

[5] DIDIER JR, Fredie e OLIVEIRA, Rafael Alexandria. Beneficio da justiça gratuita. 6 ed. Salvador: Editora Jus podivm, 2016.

[6] ABREU, Pedro Manoel et al (org). Acesso à justiça: novas perspectivasi. Florianópolis: Habitus Editora, 2019.

[7] BRASIL. CONSELHO NACIONAL DE JUSTIÇA. Justiça em números 2019. Found at https://www.cnj.jus.br/wpcontent/uploads/conteudo/arquivo/2019/08/justica_em_numer os20190919.pdf. Accessed in February 08, 2020.

[8] CAVAlCANTE, Henrique Aruke e GICO JR., Ivo Teixeira. De graça até injeção na testa: análise juseconômicada gratuidade de justiçai. Found at https://www.researchgate.net/publication/284274771_De Gra ca_ate_Injecao_na_Testa_Analise_Juseconomica_da_Gratuid ade de Justica/link/585d93d708ae8fce48fe6209/download. Accessed in February, 08, 2020.

[9] FUX, Luiz e BODART, Bruno. Processo civil e análise econômica. Rio de Janeiro: Forense, 2019.

[10] DONNINI, Rogério. Responsabilidade civil na pósmodernidade: felicidade, proteção, enriquecimento com causa e tempo perdido. Porto Alegre: Sergio Antonio Fabris Editor, 2015.

[11] NUNES, Marcelo Guedes. Jurimetria: como a estatística pode reinventar o direito. São Paulo: Editora Revista dos Tribunais, 2016. 
[12] MACKAAY, Ejan e ROUSSEAU, Stéphane. Análise econômica do direito. Tradução Rachel Sztajn. 2 ed. São Paulo: Atlas, 2015.

[13] MENDONÇA, Diogo Naves. Análise econômica da responsabilidade civil: o dano e sua quantificação. São Paulo: Atlas, 2012.
[14] POSNER, Eric. Análise econômica do direito contratual: sucesso ou fracasso. São Paulo: Saraiva, 2010.

[15] POSNER, Richard A. Economic analysis of law. 4 ed. Chicago: Little, Brown and Company, 1992. 